\title{
A Multipurpose Leguminous Plant for the Mediterranean Countries: Leucaena leucocephala as an Alternative Protein Source: A Review
}

\author{
Anna De Angelis ${ }^{1, *}$, Laura Gasco ${ }^{2}$ (D) Giuliana Parisi ${ }^{3}$ and Pier Paolo Danieli ${ }^{4}$ (D) \\ 1 Dipartimento di Agricoltura, Alimentazione e Ambiente (Di3A), Università di Catania, Via Valdisavoia 5, \\ 95123 Catania, Italy \\ 2 Dipartimento di Scienze Agrarie, Forestali e Alimentari (DISAFA), Università di Torino, Largo Paolo Braccini \\ 2, 10095 Grugliasco, Italy; laura.gasco@unito.it \\ 3 Dipartimento di Scienze e Tecnologie Agrarie, Alimentari, Ambientali e Forestali (DAGRI), Università degli \\ Studi di Firenze, Via delle Cascine 5, 50144 Firenze, Italy; giuliana.parisi@unifi.it \\ 4 Dipartimento di Scienze Agrarie e Forestali (DAFNE), Università degli Studi della Tuscia, Via S. C. de Lellis \\ snc, 01100 Viterbo, Italy; danieli@unitus.it \\ * Correspondence: anna.deangelis@unict.it
}

check for updates

Citation: De Angelis, A.; Gasco, L.; Parisi, G.; Danieli, P.P. A

Multipurpose Leguminous Plant for the Mediterranean Countries:

Leucaena leucocephala as an Alternative Protein Source: A Review. Animals 2021, 11, 2230

https://doi.org/10.3390/ani11082230

Academic Editor:

Eduarda Molina-Alcaide

Received: 21 June 2021

Accepted: 26 July 2021

Published: 29 July 2021

Publisher's Note: MDPI stays neutral with regard to jurisdictional claims in published maps and institutional affiliations.

Copyright: (C) 2021 by the authors. Licensee MDPI, Basel, Switzerland. This article is an open access article distributed under the terms and conditions of the Creative Commons Attribution (CC BY) license (https:/ / creativecommons.org/licenses/by/ $4.0 /)$.
Simple Summary: The need to address the shortage of protein ingredients linked to both territoriality and growing demand pushes research to focus attention on alternative protein sources, both vegetable and animal (insects). This review describes the characteristics, uses, strengths, and weaknesses of Leucaena leucocephala, a legume that can be used in the zootechnical field as an alternative to traditional protein sources for feed formulation.

Abstract: In tropical and subtropical regions, as well as in the internal and/or marginal Mediterranean areas, one of the most important problems related to animal production is represented by the inadequate nutritional supplies. The low productivity of the animals, often connected to reduced annual growth, is, in fact, not infrequently attributable to the low nitrogen content and the high fiber content of the local plant species and crop residues that constitute the base ingredients of the rations commonly adopted by farmers. The use of the supplementation with arboreal and shrub fodder, although often containing anti-nutritional factors and toxins that limit its use, could be a profitable way to alleviate the nutritional deficiencies of the basic diets. Leucaena leucocephala (Lam.) De Wit is native to Central America and widely naturalized in the majority of Latin American countries. It is a legume suitable for tropical and subtropical environments including the countries of the Mediterranean area. Moreover, its spread is desirable if we consider the multiple uses to which it is suitable, the considerable amount of biomass produced, and its role in preserving the environment. The aim of this work was to highlight the characteristics of Leucaena that can justify its wide diffusion. A structured analysis of strengths and weaknesses was performed accordingly. Being a good protein source for feeding livestock, it could be a species to be introduced in the inland areas of the Mediterranean countries as an alternative protein source; the limit represented by the presence of anti-nutritional factors could be overcome by feed processing and by launching targeted research programs.

Keywords: animal nutrition; chemical composition; leadtree; Ipil-Ipil; Mediterranean areas; SWOT analysis; fodder; mimosine; anti-nutritional factors

\section{Introduction}

White leadtree or Leucaena (Leucaena leucocephala) (Figure 1), also known as ipil-ipil, is native to Central America and has spread and/or naturalized all over the World at a latitude between $30^{\circ} \mathrm{N}$ and $30^{\circ} \mathrm{S}$ due to a shrub variety used as a shade tree for coffee, cocoa, hemp plantations, pepper, vanilla, and other essences $[1,2]$. 


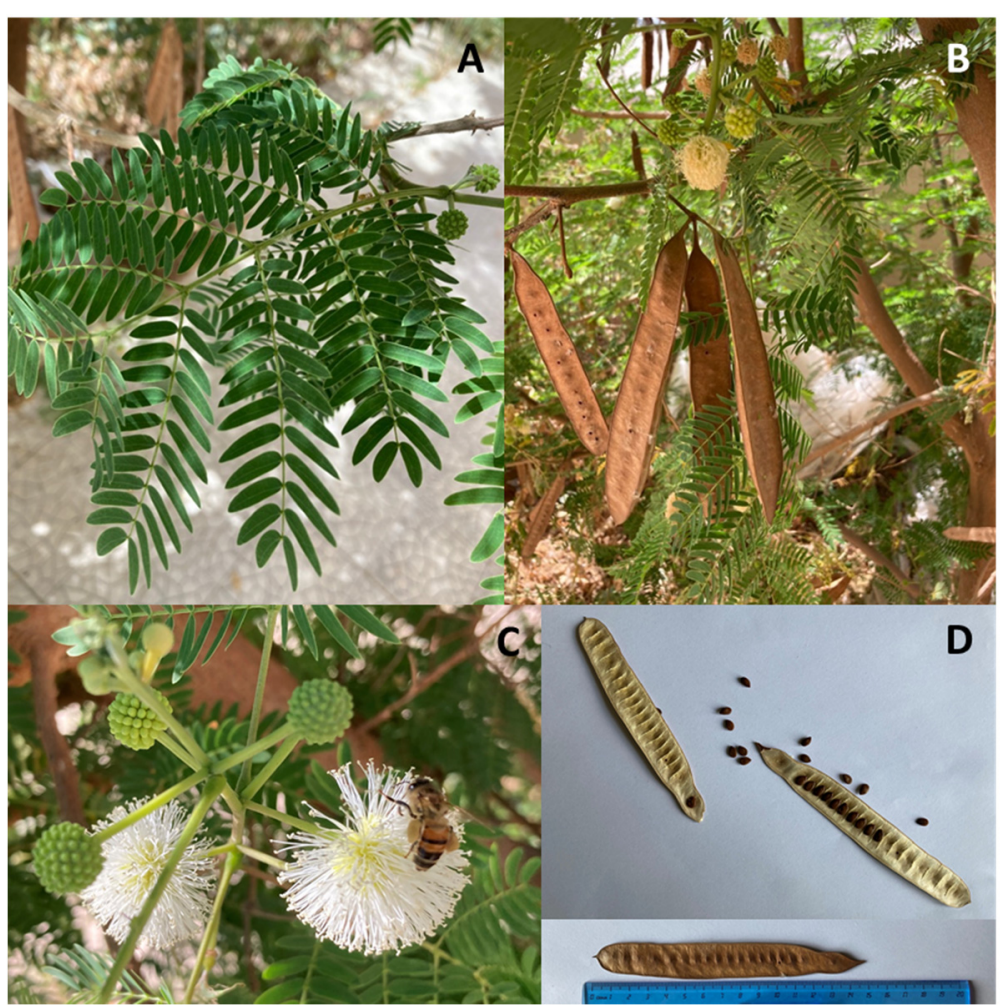

Figure 1. Leucaena leucocephala (Lam.) de Wit: (A) leaves; (B) flowers and ripened fruits; (C) honey bee foraging on Leucaena flowers; (D) pod and seeds (pictures kindly provided by Dr. Dipasquale D).

The Leucaena genus includes only 24 native species (19 diploid and five tetraploid species) [3], even though several researchers [4-6] refer to about 50 species of shrubs and trees found in the tropical and subtropical regions of North and South America, Africa, and the South Pacific and more than 800 cultivars, grouped in three main types: (1) the common type, with small and shrubby varieties that grow up to $5 \mathrm{~m}$ in height; (2) the giant type, including varieties up to $20 \mathrm{~m}$ tall, with larger leaves, pods, and seeds, and a larger trunk poorly branched; and (3) the "Peru" type with medium-sized varieties that grow up to $10 \mathrm{~m}$ in height, with lots of branches from the bottom of the trunk, and producing abundant forage with frequent pruning [1]. Undoubtedly, the morphological and ecophysiological diversities within the genus combined with the high crossability among species provide ample opportunities for genetic improvement, via traditional breeding approaches and notably via interspecific artificial hybridization, to develop genetically improved seed lines [3].

Interspecific hybridization enables plant breeders to combine superior traits from different species to form the basis of populations for the further selection and genetic improvement. Hybridization programs have been undertaken to develop new cultivars of Leucaena with the following characteristics: low mimosine forage, acid soil tolerance, psyllid resistance, cold tolerance, wood/biomass/pulp production, and sterility [7].

The optimal growth of Leucaena occurs in areas that receive an average annual precipitation of $1500 \mathrm{~mm}$, with a dry season of 4 months [2] and with an average annual temperature between 25 and $30^{\circ} \mathrm{C}$ [4]. It tolerates a wide variety of soil conditions [8], and the best growth occurs under direct sunlight in well-drained soils, from moderately alkaline (pH 7.5) to slightly acidic ( $\mathrm{pH}$ 6.0), with a salinity less than $20 \mathrm{mmhos} / \mathrm{cm}$ [9].

The purpose of the review was to highlight the characteristics of Leucaena that may justify its introduction in the inland areas of the Mediterranean countries, also as an alternative to protein sources usually used in animal feed (e.g., soybean meal, alfalfa). A Strength, Weakness, Opportunity, and Threat (SWOT) analysis [10] was adopted as a structured methodology for the aforementioned purpose. 


\section{SWOT Analysis}

In the following sections, pros and cons of using the Leucaena as protein source are assessed by a detailed analysis of literature data on the topic according to a four-box analysis framework approach: strengths, weakness, opportunities, and threats, known as SWOT analysis [10], as already performed by the authors elsewhere [11,12].

\subsection{Strengths}

The spread of Leucaena is mainly due to its multipurpose character. The characteristics of the wood (specific weight: $0.50-0.59 \mathrm{~kg} / \mathrm{cm}^{3}$; caloric value: $19.4 \mathrm{~kJ} / \mathrm{g}$ ) are such to make it particularly suitable to produce coal $[13,14]$ and paper. Being easily machinable, porous to water-soluble preservatives, and non-deformable during drying, it is used for light constructions and crates, for various types of fences, furniture, and tables [7,13]. It is also used as a shade tree in various plantations [3,7,15-17], to enrich the soil as a mulch [18] and nitrogen fixer [19-22], and for the reforestation of bare areas, slopes, and pastures $[4,8,15]$. In some rural areas of Central America and Southeast Asia, both soft seeds and leaves from Leucaena are used as vegetables in cooking; in addition, the seeds, containing more than $5.5 \%$ of fat $[4,23]$ (Table 1 ), with the palmitic, stearic, behenic, lignoceric, oleic, and linoleic acids as main components, are used as a coffee substitute $[19,24]$ and as a dewormer $[25,26]$. In Mexico, red, brown, and black pigments are extracted from the pods, leaves, and bark. The bark and roots are used as household medicines and the roots have emmenagogic and abortive properties [27]. Leucaena is also considered a good plant for honeybees (Figure 1).

Table 1. Chemical composition of Leucaena seeds [23,28].

\begin{tabular}{|c|c|}
\hline Parameter & Values \\
\hline Crude protein (\%) & $31.1 \pm 0.4$ \\
\hline Crude fat $(\%)$ & $5.6 \pm 0.4$ \\
\hline Crude fiber $(\%)$ & $13.2 \pm 0.2$ \\
\hline Dry matter (\%) & $94.8 \pm 0.1$ \\
\hline Crude ash (\%) & $4.5 \pm 0.5$ \\
\hline NFE $(\%)$ & $40.4 \pm 0.2$ \\
\hline $\mathrm{ME}(\mathrm{kcal} / \mathrm{kg})$ & $2573.3 \pm 4.2$ \\
\hline Calcium (g/kg) & $3.70 \pm 0.10$ \\
\hline Total phosphorous (g/kg) & $3.400 \pm 0.001$ \\
\hline Tannin $(\mathrm{g} / \mathrm{kg})$ & $7.5 \pm 0.2$ \\
\hline Phytate (mg/100 g) & $697.5 \pm 1.5$ \\
\hline \multicolumn{2}{|l|}{ Amino acids $(\mathrm{g} / \mathrm{kg})$} \\
\hline Cystine * & $3.50 \pm 0.1(1.13)$ \\
\hline Arginine & $26.2 \pm 2.0(8.42)$ \\
\hline Methionine & $3.6 \pm 0.1(1.16)$ \\
\hline Glutamic acid & $46.3 \pm 0.3(14.89)$ \\
\hline Threonine & $8.7 \pm 0.1(2.80)$ \\
\hline Glycine & $13.8 \pm 0.1(4.44)$ \\
\hline Alanine & $11.1 \pm 0.1(3.57)$ \\
\hline Valine & $11.1 \pm 0.2(3.57)$ \\
\hline Isoleucine & $9.3 \pm 0.3(2.99)$ \\
\hline Leucine & $18.1 \pm 0.3(5.82)$ \\
\hline Lysine & $13.9 \pm 0.2(4.47)$ \\
\hline Methionine + Cystine & $7.10 \pm 0.02(2.28)$ \\
\hline \multicolumn{2}{|l|}{ Fatty acids (\% total FA) } \\
\hline C14:0 & 2.3 \\
\hline $\mathrm{C} 16: 0$ & 19.6 \\
\hline C18:0 & 8.0 \\
\hline C18:1n-9 & 8.5 \\
\hline C18:2n-6 & 13.6 \\
\hline C18:3n-3 & 36.3 \\
\hline C20:0 & 2.4 \\
\hline SFA & 41.4 \\
\hline MUFA & 8.7 \\
\hline PUFA & 49.9 \\
\hline PUFAn-6:PUFAn-3 ratio & 0.4 \\
\hline
\end{tabular}

NFE = nitrogen-free extracts; ME = metabolizable energy; SFA = saturated fatty acids; MUFA = monounsaturated fatty acids; PUFA = polyunsaturated fatty acids; * aminoacidic content in brackets is reported as $\mathrm{g} / 15 \mathrm{gN}$. 
With reference to its possible use in the agro-zootechnical field, yields in the subtropics, where temperature limitations reduce growth rates, may be only $1.5-10 \mathrm{t}$ of edible fodder/ha/year [29]. Its resistance to the dry season guarantees the availability of good forage, when pasture or other forages have browned and show a reduction in their nutrient content [28]. For its high palatability, a digestibility between $50 \%$ and $70 \%[30,31]$, and its good nutritional value ( $22 \%-28 \%$ protein), Leucaena forage can be a valid feedstuff both for ruminants (cattle, sheep, and goats) [32,33] and for non-ruminants (pigs, rabbits, chickens, fish). Figueredo et al. [34] reported a change in the chemical composition of the Leucaena forage in relation to the age of the cut. In particular, between 30 and 90 days of age, they detected a significant increase in dry matter (18.78\% vs. $45.47 \%)$ and a significant decrease in protein $(22.90 \%$ vs. $12.31 \%)$ and ash $(6.09 \%$ vs. $3.67 \%)$ but constant values of neutral detergent fiber, acid detergent fiber, hemicelluloses, cellulose, and lignin.

The high protein and $\beta$-carotene content, which make Leucaena comparable to alfalfa fodder (Table 2), is accompanied by an amino acid composition like that of soy meal and fishmeal [33], quite rich in essential amino acids such as isoleucine, leucine, phenylalanine, and histidine. Leucaena fodder can be an excellent source of calcium, phosphorus, and other minerals, depending on the mineral availability of the soil [29-31,34-36], but it is generally deficient in sodium [30,32,34]. Not much data is available on the non-structural carbohydrates present in the leaves; Kale [37] reports the following composition: $18.6 \%$ total carbohydrates, $1 \%$ starch, $2.8 \%$ total oligosaccharides, $4.2 \%$ reducing sugars, $1.2 \%$ sucrose, and $0.6 \%$ raffinose.

L. leucocephala is a species worthy of interest in the zootechnical field especially in tropical and subtropical regions, as well as in the internal and/or marginal ones of the Mediterranean area [38-40]. Tables 2 and $3[32,33,41-49]$ show the chemical composition of Leucaena leaves, leaf meal, forage, silage, and hay.

Table 2. Chemical composition of Leucaena leaves [33,41-43] and leaf meal [32,44-47] in comparison with Alfalfa leaves [33].

\begin{tabular}{|c|c|c|c|}
\hline Parameter & Leucaena Leaves & Leucaena Leaf Meal & Alfalfa Leaves \\
\hline CP (\%DM) & $22.8-25.9$ & $23.3-29.2$ & 26.9 \\
\hline $\mathrm{EE}(\% \mathrm{DM})$ & 4.7 & $5.6-12.4$ & - \\
\hline CF (\%DM) & 20.1 & $9.5-19.2$ & - \\
\hline NDF (\%DM) & 17.4 & $23.6-40.4$ & - \\
\hline ADF (\%DM) & $20.4-25.1$ & $25.7-27.9$ & 21.7 \\
\hline ADL (\%DM) & 12.8 & $8.3-10.5$ & - \\
\hline ASH (\%DM) & $6.4-11.0$ & - & 16.6 \\
\hline NFE (\%DM) & 46.26 & $40.2-48.9$ & - \\
\hline Mimosine (\%DM) & - & 4.3 & - \\
\hline GE (MJ / kg DM) & $20.1-20.2$ & $16.2-17.8$ & 18.5 \\
\hline $\mathrm{Ca}(\mathrm{g} / \mathrm{kg} \mathrm{DM})$ & $8.0-23.6$ & $16.0-20.8$ & 31.5 \\
\hline$P(g / k g D M)$ & $2.0-3.3$ & $2.0-2.4$ & 3.6 \\
\hline $\operatorname{Mg}(\mathrm{g} / \mathrm{kg} \mathrm{DM})$ & $1.9-4.0$ & 3.4 & - \\
\hline $\mathrm{K}(\mathrm{g} / \mathrm{kg} \mathrm{DM})$ & - & 17.0 & - \\
\hline $\mathrm{Fe}(\mathrm{mg} / \mathrm{kg} \mathrm{DM})$ & - & 907.4 & - \\
\hline Zn (mg/kg DM) & - & 19.2 & - \\
\hline $\mathrm{Mn}(\mathrm{mg} / \mathrm{kg} \mathrm{DM})$ & - & $50.9-80.0$ & - \\
\hline Phenolics (g/kg DM) & 112.0 & - & - \\
\hline Tannins (g/kg DM) & $10.2-21.0$ & 10.1 & 0.13 \\
\hline$\beta$-carotene (mg/kg DM) & 536.0 & 237.5 & 253.0 \\
\hline $\operatorname{IVDMD}(\%)$ & 56.8 & - & - \\
\hline Arginine (mg/gN) & 294 & - & 357 \\
\hline Cysteine (mg/gN) & 88 & - & 77 \\
\hline Histidine (mg/gN) & 125 & - & 139 \\
\hline Isoleucine (mg/gN) & 563 & - & 290 \\
\hline Leucine (mg/gN) & 469 & - & 494 \\
\hline Lysine (mg/gN) & 313 & - & 368 \\
\hline Methionine (mg/gN) & 100 & - & 96 \\
\hline Phenylalanine (mg/gN) & 294 & - & 307 \\
\hline Threonine (mg/gN) & 231 & - & 290 \\
\hline Tyrosine (mg/gN) & 263 & - & 232 \\
\hline Valine $(\mathrm{mg} / \mathrm{gN})$ & 338 & - & 356 \\
\hline
\end{tabular}


Dry matter productivity of Leucaena varies with soil fertility and rainfall. Edible forage yields range from 3 to $30 \mathrm{t} \mathrm{DM} /$ ha/year. In deep fertile soils receiving more than $1500 \mathrm{~mm}$ of evenly distributed rainfall, Leucaena produces the largest quantities of good-quality fodder. The green leaves and legumes can be used for grazing or as fodder to be distributed in the animal feeder, administered in a fresh state or in pellets. Season of the year and cutting age affect chemical composition and digestibility of Leucaena forage; Verdecia et al. [50] found that the cell wall components (neutral detergent fiber, NDF; acid detergent fiber, ADF; lignin), calcium, and silica as well as the fiber-to-nitrogen $(\mathrm{N})$ ratios $(\mathrm{NDF} / \mathrm{N}$ and $\mathrm{ADF} / \mathrm{N})$ increased with the regrowth age in the rainy season. Meanwhile, crude protein (CP), cell content, in vitro dry matter digestibility (IVDMD), and in situ dry matter digestibility (ISDMD) decreased; similar trends were observed for NDF, ADF, lignin, $\mathrm{NDF} / \mathrm{N}$, and $\mathrm{ADF} / \mathrm{N}$ (increase with age) and for $\mathrm{CP}$, cell content, and IVDMD (decrease with age) during the dry season. The maximum values for ISDMD and silica in the dry season were found at 120 days of regrowth.

Table 3. Chemical composition (on wet weight basis, except if otherwise reported) of Leucaena forage [32], leaves' silage [48], and hay (L. leucocephala cv. Cunningham) [49].

\begin{tabular}{|c|c|c|c|}
\hline Parameter & Forage & Leave Silage & Hay \\
\hline Dry matter (\%) & - & $35.22-35.65$ & 90.55 \\
\hline Crude protein $(\%)$ & 22.03 & $21.49-22.29$ * & 15.87 \\
\hline Crude fiber (\%) & 3.50 & - & - \\
\hline NDF (\%) & 39.50 & - & 48.11 \\
\hline $\operatorname{ADF}(\%)$ & 35.10 & $31.18-33.68$ * & - \\
\hline Hemicellulose (\%) & 4.71 & - & - \\
\hline Ether extract (\%) & - & $7.76-8.22 *$ & - \\
\hline Tannins (\%) & 1.05 & - & 0.83 \\
\hline Mimosine (\%) & 2.14 & - & - \\
\hline Ash (\%) & 18.3 & - & 5.44 \\
\hline $\mathrm{Ca}(\%)$ & 1.80 & - & - \\
\hline $\mathrm{P}(\%)$ & 0.26 & - & - \\
\hline $\operatorname{Mg}(\%)$ & 0.33 & - & - \\
\hline$K(\%)$ & 1.45 & - & - \\
\hline $\mathrm{S}(\%)$ & 0.22 & - & - \\
\hline $\mathrm{Zn}(\mathrm{mg} / \mathrm{kg})$ & 169.50 & - & - \\
\hline $\mathrm{Cu}(\mathrm{mg} / \mathrm{kg})$ & 26.00 & - & - \\
\hline Acetate $(\%)$ & - & $2.00-2.90 *$ & - \\
\hline Lactate (\%) & - & $6.90-9.70$ * & - \\
\hline Oxalates (mg/kg) & 881.60 & - & - \\
\hline
\end{tabular}

For ruminants, Garcia et al. [32] found the digestible energy values of Leucaena forage ranging from 11.6 to $12.9 \mathrm{MJ} / \mathrm{kg} \mathrm{DM}$, values of total apparent digested crude protein (TADCP) ranging from 64.7 to $78.0 \%$, and $42 \%$ of rumen degradable protein, with $48 \%$ of the undegradable protein being digested post-ruminally, giving a TADCP value of $70 \%$. Possenti et al. [51] showed a reduction in methane emissions, and a consequent improvement in energy efficiency, by administering $50 \%$ of the dry substance of the diet to adult cattle of Leucaena hay, associated with ferments. McSweeney et al. [52] indicated that steers grazing on Leucaena produced approximately $28 \%$ less enteric methane than those grazing on a native grass pasture dominated by Dicanthium sp. In Australia, Taylor et al. [53] found a reduction of greenhouse gas emission and an increase in productivity of their herds grazing on Leucaena. In Mexico, cattle feeding with a diet based on Pennisetum purpureum grass supplemented with $30 \%$ foliage from Leucaena showed a decrease in methane production by $31.6 \%$ [54]. Other studies found that shifts in the bacterial populations with increases in the methanogen components are the likely basis for alterations in methanogenesis in Leucaena forage-fed cattle and identified a practical method of measuring methane emissions in grazing animals $[55,56]$. 
Heifers fed with L. leucocephala incorporated into the ration from $20 \%$ to $80 \%$ DM had no effect on dry matter and organic matter intake and digestibility, but energy losses in the form of methane emission were reduced to $61 \%$ (with Leucaena forage included at $80 \% \mathrm{DM}$ level), in comparison to the no-Leucaena diet, even though the energy losses in the urine increased linearly with the increased inclusion of Leucaena in the diet [57]. The optimum level of inclusion of $L$. leucocephala in cattle rations as a source of condensed tannins lies in the range of $20-40 \%$ of ration dry matter [57].

Research carried out on buffaloes of the Murrah breed [58], fed with three levels of Leucaena leaves in their diet $(0,10$, or $20 \mathrm{~g}$ DM $/ \mathrm{kg} \mathrm{LBW})$, revealed a rapid metabolization of mimosine. Other authors [59] showed an improvement in the digestibility of the fiber and in the nitrogen balance by administering Leucaena forage added with polyethylene glycol.

In sheep, Leucaena leaves provided at a level of 20\% (150 g DM/day) of the diet did not act entirely as a substitute feed, but to some extent increased the intake of basal diet itself. This would indicate that not only relatively poor degradability of Leucaena protein in the rumen makes it a valuable source of by-pass protein for supplementation of low-quality roughage, but also that the supplementation with Leucaena would improve the supply of energy to the animals [60].

Singh et al. [61] noted an increased activity of protozoa, bacteria, and rumen fungi by supplementing the diet of adult sheep with Leucaena. Santana et al. [62] found better intake and nutrient digestibility in lambs when fed with silage mixture with Leucaena and better $\mathrm{N}$ retention when fed alone. In lambs, the replacement of mustard seeds with Leucaena seeds, as a protein source up to $50 \%$, did not produce adverse effects on the ingestion of the dry matter, the use of nutrients, the nitrogen balance, and the growth performance [63].

Goats are well adapted to Leucaena and can be productive on diets containing up to 100\% Leucaena, because of bacterial and hepatic detoxification. Incorporation of Leucaena into goat production systems can improve live weight gains, milk production, worm control, and reproduction. Akingbade et al. [64] pointed out the absence of toxicosis in goat pasturing on Leucaena, justifying it with the ruminal colonization with Synergistes jonesii. Successful feeding systems for goats can be based on both grazed sylvo-pastoral systems and cut-and-carry intensive systems, although there is a lack of farming system research examining the integration of Leucaena into goat production systems or documentation of the feasibility of these practices [65]. In addition, other investigations on goats $[66,67]$ observed the effects of mineral supplementation on nutritive value of Leucaena and the toxicity of 2,3-DHP. In particular, even though the addition of iodine did not increase dry matter intake, protein, and metabolizable energy digestibility, a significant and positive effect was reported as far as the nitrogen retention; also, supplementation with ferric sulphate, magnesium sulphate, and zinc sulphate appeared to prevent toxicosis, probably due to a chelating action.

In the feeding of rabbits, it is possible to include Leucaena into the diet at a rate of $25 \%$, even if no adverse effects with inclusions of $40 \%-60 \%$ in balanced diets have been noted. Santos-Ricalde et al. [68] suggested that, when restricted up to $30 \%$ and supplemented with either Moringa oleifera or L. leucocephala, the growth performance remained unaffected, and the feed cost was reduced.

Raharjo et al. $[69,70]$ attributed to Leucaena a good palatability $(\geq 30 \%$ of the total intake) and high digestibility values when administered to rabbits. Leucaena seems to be the favorite essence of New Zealand White rabbits in the dry season [71]; to obtain better carcass characteristics, in the same breed, the level of inclusion of Leucaena must be less than $50 \%$ [72].

Al-Amin et al. [73] concluded that a pelleted diet containing 10\% Leucaena leaf meal, as a replacement for soybean meals and copra cake in complete feed, improved the growth performance of New Zealand White rabbit male. As a matter of fact, the daily weight 
gain increased to a $10 \%$ Leucaena inclusion level and feed conversion and cost per gain decreased accordingly [73].

Using leaf meal as a supplement for broilers, a daily growth of 100-110 g per week can be determined; in addition, in quantities not exceeding $5 \%$ of the diet, leaf meal could be used with other xanthophyll sources to give a satisfactory color to the carcass [74]. Adult chickens fed with Leucaena leaf meal up to $7 \%$ of the diet showed an increase in the use of crude protein and metabolizable energy [75]. Dumorné [76] found positive effects on weight gain, body weight, and feed intake of laying hens with inclusion of Leucaena leaves meal from 6 up to $12 \mathrm{~g} / \mathrm{bird} /$ day, in comparison with the control diet without Leucaena. Feeding broiler chicken with boiled L. leucocephala meal (10\% of the diet) was recommended since it furnished high carcass and meat attributes of broiler chicken [77]. In research conducted on laying hens, a consistent increase in the yolk color, with inclusions equal to $16 \%$ of the diet [78], was found.

On growing pigs, the use of Leucaena leaves did not produce significant increases in average weight, but a $47 \%$ increase in food conversion [79]. Ekpenyong [80] claimed that it may be possible to use Leucaena leaf meal as a means of meeting the amino acid requirements of pigs fed in the tropics.

Leucaena sounds promising also for fish feeding. Isonitrogenous diets $(\mathrm{CP}$ about $30 \%$ ) with protein from Leucaena leaf (raw and soaked) replacing from $25 \%$ to $75 \%$ animal proteins (fishmeal) were tested in Indian major carp (Labeo rohita) fingerlings, in a 77-day growth trial [81]. Raw Leucaena did not exhibit promising results, but soaked Leucaena leaves at the lowest inclusion level resulted better than the other diets as far as feed acceptability, growth, feed conversion, protein utilization and digestibility, and body composition, but a $50 \%$ fish meal protein replacement allowed researchers to obtain the highest economic returns due to the lower high-price fishmeal inclusion. Inoculation of bacterial strains of Bacillus subtilis or B. circulans from other fish species allowed researchers to include Leucaena leaf meal at a $30 \%$ or $40 \%$ level, replacing other ingredients in a fishmeal diet for Indian major carp with no adverse effects [82]. In Nile tilapia (Oreochromis niloticus) fingerlings, the replacement of berseem (Trifolium alexandrinum) leaf meal with Leucaena leaf meal (dried at $60{ }^{\circ} \mathrm{C}$ for $48 \mathrm{~h}$ or autoclaved for $15 \mathrm{~min}$ ) resulted in a better growth rate (0.067-0.144 g/day), feed conversion ratio (1.52-2.72 $\mathrm{g} \mathrm{DM} / \mathrm{g})$, protein efficiency (1.03-2.06), and energy utilization $(9.8-18.7 \%)$ than other isonitrogenous and isoenergetic experimental diets [83]. Leucaena leaf (soaked and dried) meal was tested up to $20 \%$ inclusion in diets for African catfish fingerlings by partially replacing fishmeal, soymeal, and corn meal [84]. After 8 weeks, all the measured growth parameters, feed conversion ratio (4.33), protein efficiency ratio (0.22), and protein and fat percentages in carcass $(19.15 \%$ and $12.86 \%$, respectively) in fish resulted as better the higher the inclusion level of Leucaena leaf meal was, with no differences as far as the survival rate. Meals from Leucaena seeds sun-dried, toasted, and soaked in water or in alkaline solution were tested as ingredients for isonitrogenous diets $(40 \% \mathrm{CP})$ in a 2-week digestibility trial using African catfish (Clarias gariepinus) fingerlings with no adverse effect on the specimen survival [85]. Seeds soaked in water performed better as far as the mean weight gain $(0.32 \mathrm{~g})$, feed conversion ratio (0.94), and energy and protein digestibility (73.6 and $70.2 \%$, respectively), and marginal positive effects were also observed as far as the protein content of the fish carcass.

\subsection{Weakness}

The occurrence of tannins and other phenolic compounds (both in fodder and in leaf flour) can represent a limitation in the use of Leucaena for monogastric animals; in addition to tannins and phenolic compounds, the most studied and most toxic anti-nutritional factor [33] is a non-protein nitrogen compound, i.e., the mimosine amino acid (Figure 2). Despite having many positive nutritional benefits, Leucaena contains the toxic non-protein free amino acid mimosine, $\beta$-N(3-hydroxy-4-pyridone)- $\alpha$-amino propionic acid (Figure 2$)$, and up to $9 \%$ dry matter (DM) in young leaves and $4-7 \%$ DM in seeds [86]. Mimosine 
accounts for approximately $60 \%$ of the total free amino acids $(4.89 \mathrm{~g} / 100 \mathrm{~g})$ in L. leucocephala seeds [87].<smiles>NC(Cn1ccc(=O)c(O)c1)C(=O)O</smiles>

Figure 2. Chemical structure of $\beta-\mathrm{N}(3$-hydroxy-4-pyridone)- $\alpha$-amino propionic acid (mimosine).

Overall, ruminants fed with Leucaena showed symptoms of toxicity due to the presence of mimosine and metabolites derived from its rumen degradation: In ruminants, the primary metabolite of mimosine is the compound 3-hydroxy-4(1H)-pyridine (3,4-DHP) [88], which, in the presence of certain ruminal microbes, can be further converted to its isomer 2,3-dihydroxypyridine (2,3-DHP) [89].

Biosynthesis [90,91], degradation [92-94], and biochemical effects [35,95-97] of mimosine have been extensively examined, but to date many aspects are not yet known. The mechanism that induces toxicosis is complicated and several theories have been put forward to explain it [40].

Mimosine is acutely antimitotic [88], inhibiting the synthesis of DNA [98,99], particularly in rapidly dividing cells [100,101], and can cause damage to internal organs [102]. The symptoms ascribed to mimosine include alopecia [103,104], esophageal lesions [105], fetal abortions [106], low bull fertility [107], and death [102,105,108].

Structurally, mimosine is a tyrosine analogue $[103,109]$, capable of inhibiting enzyme functions such as tyrosine decarboxylase and tyrosinase [110]. The inhibition of these enzymes and the inhibition of RNA synthesis in the follicle bulbs of hair cells, along with the incorporation of mimosine into biologically vital proteins [100] can result in depilation of actively growing hairs. For this reason, alopecia is one of the most reported symptoms, when animals are first introduced to Leucaena, and can occur within 7 days on 100\% Leucaena-based diets [103].

The metabolite 3,4-DHP acts as a potent goitrogen. By inhibiting essential peroxidaseand lactoperoxidase-catalyzed reactions [110-112], the iodination of tyrosine in the binding step of the thyroid is inhibited. Compounding the goitrogenic effects of 3,4-DHP is the fact that it strongly chelates with metal ions [100], forming complexes with $\mathrm{Zn}, \mathrm{Cu}$, and Fe, in particular, leading to excretion and depletion of these minerals [113]. The 2,3-DHP has been shown to reduce dry matter intake [114] and milk production in dairy cows [115].

There are numerous studies on possible solutions to allow the use of Leucaena and to overcome its limitations due to the presence of mimosine. As an example, the heat treatment of Leucaena leaves by exposure to sunlight or high temperatures $[103,116,117]$ can significantly reduce the content in mimosine. Wet treatments, such as cooking [118], immersion in hot water [118], and autoclave treatment [37,119], are believed to do so more effectively than dry heat treatments $[35,120]$. Removal and/or extraction of mimosine can be effectively accomplished with the use of $0.05 \mathrm{~N}$ sodium acetate [121] or urea and sodium bicarbonate [122], capable of removing high percentages of mimosine up to $80 \%$ and $88 \%$, respectively. Silage seems to be an effective method for reducing the mimosine content in Leucaena [123]. A possible solution could also be the selective breeding of low-mimosine Leucaena hybrids [124].

In ruminants, chewing with alkaline saliva and incubation in the rumen induce the degradation of mimosine with the production of 3,4-DHP, a powerful goitrogenic [35,96,125]; 
nevertheless, rumen inoculations with rumen fluid of adapted animals, cultures enriched with degrading rumen bacteria, and pure cultures of $S$. jonesii have all been successfully used to create rumen populations capable of degrading 3,4-DHP and preventing Leucaena toxicosis [96,125-127]. Gupta and Atreja [128], working on gradual adaptation to Leucaena leaf meal in cattle, identified the presence of two types of micro-organisms degrading mimosine in 3,4-DHP and 2,3-DHP and affirmed that the type degrading 2,3-DHP can be inhibited with the presence of 3,4-DHP.

Recent studies conducted in Australia and Indonesia highlighted the possibility of avoiding the use of $S$. jonesii inoculation in cattle grazing on Leucaena, having detected a very short duration of mimosine toxicosis symptoms; they attributed this result to the contribution of other types of microorganisms in the rumen and to the conjugation process in the liver and suggested the most suitable methods for determining the presence of urinary mimosine degradation products. They suggested further research that may confirm their hypotheses [129-131].

\subsection{Opportunities}

Among all tropical legume plants, Leucaena probably offers the widest assortment of uses [8]. In addition, for its leafiness and copious beautiful flowers, Leucaena can be used as ornamental plant to beautify the landscape; it could be profitably widespread in the internal or marginal areas of the Mediterranean countries due to its characteristics other than to be an alternative protein source to valuable fodder for feeding polygastric and monogastric animals, being also useful for reducing methane emissions in ruminant farming, i.e.,

- It is highly productive and adaptable to various types of environmental conditions (rainfall from 250 to $1700 \mathrm{~mm} / \mathrm{y}$, neutral-alkaline soil types from rocky to heavy clay to coral) [8], with some exceptions as far as the winter cold tolerance that can limit the spread of this species at high latitudes, even though there can be some variability for the different accessions [132].

- It is useful for honeybees and other pollinating insects [133,134]. In honey from stingless bees (Melipona spp.) in Brazil, Leucaena pollen grains can be found at high levels $(>13 \%)$ in about half of the samples [135]. In Tanzania, used in an ecological restoration program, Leucaena impacted positively on the pollinator abundance (butterflies, bees, beetles) with tangible returns in terms of Leucaena seed yield [136]. In some areas of the Yucatan peninsula, Mexico, Leucaena pollen was found to be an important protein source for the European subspecies of the honeybee (Apis mellifera L.) [137].

- It is a soil improver plant species $[1,131]$ and can be planted as a living fence around the garden as ornamental, fire break, and wind break [138].

- It is useful as a dual-purpose plant, suitable for producing both biofuels and feedstuffs. Its kernel oil can be converted into biodiesel $[138,139]$, leaving a defatted residue as a by-product that can be conveniently valorized for bioethanol production [140] or for feed-making purposes. In addition, some Leucaena cultivars, such as the Terramba, can be used for short rotation coppicing that can be conveniently integrated with the recovery of the leave mass that can be addressed to the livestock feeding [141].

- It is rich in several phytochemicals that make its seeds and leaves a promising source of pharmacological compounds also for veterinary applications. Water and hydro-alcoholic extract of Leucaena seeds exhibited good antioxidant power assessed through four different assays, partially decoupled to the tannins' content [142]. Seed oil exhibited interesting antimicrobial activity on both mastitis caused by Gram-positive and Gram-negative bacteria such as Staphylococcus aureus and Escherichia coli [143]. Hydroalcoholic extracts of Leucaena leaves caused an average $54 \%$ reduction of the gastrointestinal nematode burden in Katahdin $\times$ Pelibuey crossbreed male lambs after 43 and 63 days of administration [144]. Protein extracts from Leucaena seeds showed anti-hatching activity on the eggs of the gastrointestinal nematode Haemonchus contor- 
tus in laboratory trials, probably due to the high protease and chitinase activity of the Leucaena seed extracts [145].

In such areas, as most of the research in the zootechnical field has been carried out in the countries where it is indigenous or naturalized for a long time (Mexico, Australia, Indonesia), it would be worth starting experimental programs aimed at identifying the best use.

\subsection{Threats}

Due to its high adaptability and competitivity, its invasive trait plays a role in ecosystems both under harsh [146] and wet climate and edaphic condition [147,148]. For these reasons, L. leucocephala is considered an invasive alien species in many countries [148-150]. Several studies have been conducted to identify the mechanisms that determine these traits, with the aim of finding adequate containment systems [151-153]. The exploitation of Leucaena for agroforestry or crop/pasture purposes should be carefully evaluated after a thorough cost-to-benefit analysis, in non-native tropical regions [148], even though it seems a minor threat in temperate and/or harsh regions wherever seasonal low temperatures or low water availability can limit the growing and diffusive potentials of this leguminous tree [146]. In temperate areas, special care should be taken to the seed propagation of Leucaena through waterways, rain washout, and unintentional cultivation [154]. The Leucaena invasive potential can be further controlled through a careful selection of more vigorous/less seed producer genotypes [155]. Due to different perspectives, to date the right exploitation of this interesting leguminous tree outside its native areal is a matter of debate [156].

\section{Conclusions}

Among the vegetable sources, L. leucocephala seems to be suitable to fill the deficiencies of other sources, especially from a protein and amino acid point of view, representing, moreover, an economically sustainable nutritional source. Being highly productive and having a medium-high protein content, it can be used as feedstuff, especially in those areas where the problem of finding alternative protein sources arises, such as the inland areas of the Mediterranean countries. Leucaena forage can be a valid food both for ruminants and for non-ruminants as well. Its limited use can be due to the presence of antinutritional factors, especially tannins and mimosine, but the research proved that these constraints can be overcome in several ways, not last the search of low anti-nutritional genotypes. Leucaena is also a plant worthy of interest for the reduction of methane production by ruminants when fed with Leucaena due to the presence of tannins.

Last but not least, the interest in L. leucocephala is linked to its versatility, which makes it a multipurpose plant that can provide several usage options: ornamental, fire break and windbreak, oil extraction and biofuel's production, sources of pharmacological compounds also for veterinary applications, and forage plant for honeybees and other pollinators.

Author Contributions: A.D.A. planned and wrote the manuscript; P.P.D. wrote the manuscript and prepared the figures and the tables; G.P. and L.G. supervised the work and contributed reviewing the whole manuscript and preparing the reference list. All authors have read and agreed to the published version of the manuscript.

Funding: This research received no external funding.

Institutional Review Board Statement: Not applicable.

Informed Consent Statement: Not applicable.

Data Availability Statement: Not applicable.

Acknowledgments: The authors wish to thank Daniele Dipasquale for providing high-resolution pictures of Leucaena plant details shown in Figure 1. The Leucaena pictures were shot in Scicli (Sicily, Italy). 
Conflicts of Interest: The authors declare no conflict of interest.

\section{References}

1. National Academy of Sciences. Leucaena: Promising Forage and Tree Crop for the Tropics, 2nd ed.; National Academy of Sciences: Washington, DC, USA, 1984; p. 100. Available online: https://agris.fao.org/agris-search/search.do?recordID=XF2016073798 (accessed on 23 February 2021).

2. Van Den Beldt, R.J.; Brewbaker, J.L. Leucaena Wood Production and Use; Nitrogen Fixing Tree Association: Waimanalo, HI, USA, 1985; p. 50.

3. Abair, A.; Hughes, C.E.; Bailey, D. The evolutionary history of Leucaena: Recent research, new genomic resources and future directions. Trop. Grassl. 2019, 7, 65-73. [CrossRef]

4. Allen, O.N.; Allen, E.K. The Leguminosae: A Sourcebook of Characteristics, Uses and Nodulation; University of Wisconsin Press: Madison, WI, USA, 1981; p. 812.

5. $\quad$ Brewbaker, J.L. Giant Leucaena (Koa haole) Energy Tree Farm; Hawaii Natural Energy Institute: Honolulu, HI, USA, $1980 ;$ p. 90.

6. Hutton, E.M.; Gray, S.G. Problems in adapting Leucaena glauca as a forage in the Australian tropics. Emp. J. Experim. Agric. 1959, 27, 187-196.

7. Dalzell, S.A. Leucaena cultivars-current releases and future opportunities. Trop. Grass. 2019, 7, 56-64. [CrossRef]

8. National Academy of Sciences. Firewood Crops: Shrub and Tree Species for Energy Production; National Academy of Sciences: Washington, DC, USA, 1980; p. 237.

9. Tomar, O.S.; Gupta, R.K. Performance of some forest tree species in saline soils under shallow and saline watertable conditions. Plant Soil. 1985, 87, 329-335. [CrossRef]

10. Leigh, D. SWOT Analysis. In Handbook of Human Performance Technology. Principles, Practices, and Potential; Pershing, J.A., Ed.; John Wiley \& Sons, Inc.: Hoboken, NJ, USA, 2006; p. 1089.

11. Gasco, L.; Acuti, G.; Bani, P.; Dalle Zotte, A.; Danieli, P.P.; De Angelis, A.; Fortina, R.; Marino, R.; Parisi, G.; Piccolo, G.; et al. Insect and fish by-products as sustainable alternatives to conventional animal proteins in animal nutrition. It. J. Anim. Sci. 2020, 19, 360-372. [CrossRef]

12. Parisi, G.; Tulli, F.; Fortina, R.; Marino, R.; Bani, P.; Dalle Zotte, A.; De Angelis, A.; Piccolo, G.; Pinotti, L.; Schiavone, A.; et al. Protein hunger of the feed sector: The alternatives offered by the plant world. It. J. Anim. Sci. 2020, 19, 1204-1225. [CrossRef]

13. Mac Dicken, K.G. Nitrogen Fixing Trees for Wastelands; FAO Regional Office for Asia and the Pacific [RAPA]-Food and Agriculture Organization of the United Nations: Bangkok, Thailand, 1988; p. 104.

14. Tang, J.L. Property and utilization of wood from fast grown Leucaena in Taiwan. In Proceedings of the 18th IUFRO World Congress, Ljubljana, Yugoslavia, 7-21 September 1986; Actas, Division 2. Volume 2, pp. 469-478.

15. Dassanayake, M.D. Revised Handbook to the Flora of Ceylon; Amerind Publishing Co.: New Delhi, India, $1980 ;$ p. 508.

16. Joshi, H.B. The Silviculture of India Trees; Government of India Press: New Delhi, India, 1983; Volume 4, p. 344.

17. Newton, K.; Thomas, P. Role of NFTs in cocoa development in Samoa. Nitr. Fix. Tree Res. Rep. 1983, 1, 15-17.

18. Azeez, J.O. Recycling organic waste in managed tropical forest ecosystems: Effects of arboreal litter types on soil chemical properties in Abeokuta, southwestern Nigeria. J. For. Res. 2019, 30, 1903-1911. [CrossRef]

19. Dijkman, M. Leucaena-A promising soil erosion control plant. Econ. Bot. 1950, 4, 337-349. [CrossRef]

20. Lugo, A.E.; Wang., D.; Bormann, F.H. A comparative analysis of biomass production in five tropical tree species. For. Ecol. Manag. 1990, 31, 153-166. [CrossRef]

21. Torres, F. Potential contribution of Leucaena hedgerows intercropped with maize to the production of organic nitrogen and fuelwood in the lowland Tropics. Agrof. Syst. 1983, 1, 323-333. [CrossRef]

22. Thomas, S.C.; Halim, M.A.; Gale, N.V.; Sujeeun, L. Biochar enhancement of facilitation effects in agroforestry: Early growth and physiological responses in a maize-Leucaena model system. Agrof. Syst. 2019, 93, 2213-2225. [CrossRef]

23. Malik, M.; Mardiati, Z.; Yetti, M.; Khasrad, K.; Anuraga, J. Fatty acids composition and bio-hydrogenation reduction agents of tropical forages. Biodiversity 2019, 20, 1917-1922.

24. Little, E.L., Jr.; Wadsworth, F.H. Common trees of Puerto Rico and the Virgin Islands. Agric. Handb. 1964, 249.

25. Ademola, I.O.; Idowu, S.O. Anthelmintic activity of Leucaena leucocephala seed extract on Haemonchus contortus-infective larvae. Veter. Rec. 2006, 158, 485-486. [CrossRef]

26. Athanasiadou, S.; Kyriazakis, I.; Jackson, F.; Coop, R.L. Direct anthelmintic effects of condensed tannins towards different gastrointestinal nematodes of sheep: In vitro and in vivo studies. Veter. Paras. 2001, 99, 205-219. [CrossRef]

27. Standley, P.C. Contributions from the National Herbarium. Trees and Shrubs of Mexico; Government Printing Office: Washington DC, USA, 1922; Volume 23, p. 1721.

28. Ahmed, M.E.; Abdelati, K.A. Chemical composition and amino acids profile of Leucaena leucocephala seeds. Int. J. Poult. Sci. 2009, $8,966-970$.

29. Scapinello, C.; Furlan, A.C.; Jobim, C.C.; de Faria, A.G.; Figueiredo, D.F.; Hernandes, A.B. Valor nutritivo e utilizaçao do feno de leucena (Leucaena leucocephala cv. Cunningham) para Coelho semcrescimento. Acta Scient. 2000, 22, 829-833.

30. Brewbaker, J.L.; Hedge, N.; Hutton, E.M.; Jones, R.J.; Lowry, J.B.; Moog, F.; Van derBelt, R. Leucaena: Forage Production and Use; NFTA, Cornell University: New York, NY, USA, 1985; p. 39. 
31. Vietmeyer, N.; Cottom, B.; Ruskin, F.R. Leucaena, Promising Forage and Tree Crop for the Tropics; National Academy Press: Washington, DC, USA, 1977; p. 115. Available online: https://www.nap.edu/catalog/21315/leucaena-promising-forage-and-tree-crop-forthe-tropics (accessed on 23 February 2021).

32. Garcia, G.W.; Ferguson, T.U.; Neckels, F.A.; Archibald, K.A.E. The nutritive value and forage productivity of Leucaena leucocephala. Anim. Feed Sci. Tech. 1996, 60, 29-41. [CrossRef]

33. D'Mello, J.P.F.; Thomas, D. Animal feed. In Leucaena: Promising Forage and Tree Crops for the Tropics; Rushkin, F.R., Ed.; National Academy of Sciences: Washington, DC, USA, 1977; p. 302.

34. Figueredo, E.S.; Rodrigues, R.C.; de Araújo, R.A.; dos Santos Costa, C.; de Sousa Santos, F.N.; da Silva, I.R.; Ribeiro de Jesus, A.P.; dos Santos Araújo, J.; da Silva Cabra, L.; Ribeiro Araújo, I.G. Maturity dependent variation in composition and characteristics of potentially digestible tissues of leucena. Sem. Ciênc. Agr. Londrina 2019, 40, 3133-3142. [CrossRef]

35. Ter Meulen, U.; Struck, S.; Schulke, E.; El-Harith, E.A. A review on the nutritive value and toxic aspects of Leucaena leucocephala. Trop. Anim. Prod. 1979, 4, 113-126.

36. Lou, S.N.; Hou, F.J.; Ren, J.Z. Evaluation of grassland agricultural productivity by food equivalent unit. Acta Pratac. Sin. 2019, 28, $1-16$.

37. Kale, A.U. Nutritive Value of Leucaena leucocephala(subabul). Ph.D. Thesis, University of Bombay, Mumbai, India, 1987.

38. De Angelis, A. Leucaena leucocephala (Lam.) de Wit. Tec. Agric. 2008, 3, 49-69.

39. Panjaitan, T.; Waldron, S.; Halliday, M.J.; Ash, A.; Morris, S.T.; Shelton, H.M. Adoption of Leucaena-based feeding systems in Sumbawa, eastern Indonesia and its impact on cattle productivity and farm profitability. Trop. Grass. 2019, 7, 428-436.

40. De Angelis, A. Una Leguminosa da Foraggio: Leucaena leucocephala (Lam.) de Wit; Aracne: Roma, Italy, $2012 ;$ p. 56.

41. Devendra, C. The nutritive value of Leucaena leucocephala cv. Peru in balance and growth studies with goats and sheep. Res. Bull. 1982, 10, 138-150.

42. Karachi, M. Variation in the nutritional value of leaf and stem fractions of nineteen Leucaena lines. Anim. Feed Sci. Tech. 1998, 70, 305-314. [CrossRef]

43. Tangendjaja, B.; Lowry, J.B.; Wills, R.B.H. Changes in mimosine, phenol, protein and fibre content of Leucaena leucocephala leaf during growth and development. Aust. J. Exp. Agric. 1986, 26, 315-317. [CrossRef]

44. D'Mello, J.P.F.; Taplin, D.E. Leucaena leucocephala in poultry diets for the topics. World Rev. Anim. Prod. 1978, 14, 41-47.

45. Islam, M.; Nahar, T.N.; Islam, M.R. Productivity and nutritive value of Leucaena leucocephala for ruminant nutrition. Asian-Austral. J. Anim. Sci. 1995, 8, 213-217. [CrossRef]

46. Abou-Elezz, F.M.K.; Sarmiento-Franco, L.; Santos-Ricalde, R.; Solorio-Sanchez, F. Nutritional effects of dietary inclusion of Leucaena leucocephala and Moringa oleifera leaf meal on Rhode Island Red hens' performance. Cub. J. Agric. Sci. $2011,45,2$.

47. Aye, P.A.; Adegun, M.K. Chemical composition and some functional properties of Moringa, Leucaena and Gliricidia leaf meals. Agric. Biol. J. N. Am. 2013, 4, 71-77. [CrossRef]

48. Angthong, W.; Cheva-Isarakul, B.; Promma, S.; Cheva-Isarkul, B. Beta-carotene, mimosine and quality of Leucaena silage kept at different duration. Nat. Sci. 2007, 41, 282-287.

49. Scapinello, C.; Antunes, E.B.; Melo, E.V.I.; Furlan, A.C.; Jobim, C.C. Nutritive value and utilization of Leucaena Hays (Leucaena leucocephala \& Leucaena leucocephala cv. Cunningham) for growing rabbits. In Proceedings of the 7th World Rabbit Science, Valencia, Spain, 4-7 July 2000; Volume C, pp. 423-428.

50. Verdecia, D.M.; Herrera, R.S.; Ramirez, J.L.; Leonard, I.; Bodas, R.; Andrés, S.; Giraldez, F.J.; Valdes, C.; Arceo, Y.; Paumier, M.; et al. Effect of age of regrowth, chemical composition and secondary metabolites on the digestibility of Leucaena leucocephala in the Cauto Valley, Cuba. Agric. Syst. 2020, 94, 1247-1253. [CrossRef]

51. Possenti, R.A.; Franzolin, R.; Schammas, E.A.; Demarchi, J.J.A.D.A.; Frighetto, R.D.S.; De Lima, M.A. Effects of Leucaena and yeast on rumen fermentation and methane emissions in cattle. Rev. Brasil. Zoot. 2008, 37, 1509-1516. [CrossRef]

52. McSweeney, C.S.; Tomkins, N. Impacts of Leucaena Plantations on Greenhouse Gas Emissions in Northern Australian Cattle Production Systems; Final Report; M.L.A, Locked Bag 991 North Sydney: Sydney, Australia, 2015; pp. 1-56.

53. Taylor, C.A.; Harrison, M.T.; Telfer, M.; Eckard, R. Modelled greenhouse gas emissions from beef cattle grazing irrigated Leucaena in northern Australia. Anim. Prod. Sci. 2016, 56, 594-604. [CrossRef]

54. Albores-Moreno, S.; Alayón-Gamboa, J.A.; Miranda-Romero, L.A.; Alarcón-Zúñiga, B.; Jiménez-Ferrer, G.; Ku-Vera, J.C.; PiñeiroVázquez, A.T. Effect of tree foliage supplementation of tropical grass diet on in vitro digestibility and fermentation, microbial biomass synthesis and enteric methane production in ruminants. Trop. Anim. Health Prod. 2019, 51, 893-904. [CrossRef]

55. Tomkins, N.; Harrison, M.; McSweeney, C.S.; Denman, S.; Charmley, E.; Lambrides, C.J.; Dalal, R. Greenhouse gas implications of Leucaena-based pastures. Can we develop an emissions reduction methodology for the beef industry? Trop. Grass. 2019, 7, 267-272. [CrossRef]

56. Tomkins, N.W.; Charmley, E. Herd-scale measurements of methane emissions from cattle grazing extensive sub-tropical grasslands using the open-path laser technique. Animals 2015, 9, 2029-2038. [CrossRef] [PubMed]

57. Piñeiro-Vázquez, A.T.; Jiménez-Ferrer, G.O.; Chay-Canul, A.J.; Casanova-Lugo, F.; Díaz-Echeverría, V.F.; Ayala-Burgos, A.J.; Solorio-Sánchez, F.J.; Aguilar-Pérez, C.F.; Ku-Vera, J.C. Intake, digestibility, nitrogen balance and energy utilization in heifers fed low-quality forage and Leucaena leucocephala. Anim. Feed Sci. Tech. 2017, 228, 194-201. [CrossRef] 
58. Ferreira, T.A.; Alcantara, P.B.; Beisman, D.A.; Pereira, A.M.F. Qualitative evaluation of the DHP (dihidroxipiridine) in the urine of buffaloes fed with Leucaena leucocephala. In Proceedings of the 6th Congress on Zootechny, Lisbon, Portugal, 7-9 November 1996; p. 1810.

59. Jetana, T.; Vongpipatana, C.; Usawang, S.; Thongruay, S. The use of tropical protein-rich leaves as supplements to Thai swap buffalo receiving a basal diet of rice straw and treated Leucaena (Leucaena leucocephala). Trop. Anim. Health Prod. 2011, 43, 57-67. [CrossRef]

60. Bamualim, A.; Weston, R.H.; Hogan, J.P.; Murray, R.M. The contributions of Leucaena leucocephala to post ruminal protein for sheep fed tropical pasture hay supplemented with urea and minerals. Anim. Prod. Aust. 1984, 15, 255-258.

61. Singh, S.; Kundu, S.S. Comparative rumen microbial population in sheep fed Dicantium annulatum grass supplemented with Leucaena leucocephala and Hardwickia binata tree leaves. Liv. Res. Rural Dev. 2011, 23, 1.

62. Santana, A.A.; Cheng, L.; Verdecia, D.M.; Ramírez, J.L.; López, S.; Cisneros, M.V.; Rugoho, I.; Maxwell, T.M.R.; Al-Marashdeh, O. Effect of a mixed silage of king grass (Cenchrus purpureus) and forage legumes (Leucaena leucocephala or Gliricidia sepium) on sheep intake, digestibility and nitrogen balance. Anim. Prod. Sci. 2019, 59, 2259-2264. [CrossRef]

63. Singh, S.; Kundu, S.S.; Negi, A.S.; Gupta, S.K.; Singh, N.P.; Pachouri, V.C. Leucaena seeds as protein supplement in the rations of growing sheep. Asian-Austral. J. Anim. Sci. 2002, 15, 1433-1438. [CrossRef]

64. Akingbade, A.A.; Nsahlai, I.V.; Morris, C.D.; Iji, P.A. Field activities and blood profile of pregnant South African indigenous goats after receiving dihydroxy pyridone-degrading rumen bacteria and grazing Leucaena leucocephala-grass or natural pastures. $J$. Agric. Sci. 2002, 138, 103-113. [CrossRef]

65. Cowley, F.C.; Roschinsky, R. Incorporating Leucaena into goat production systems. Trop. Grass. 2019, 7, 173-181. [CrossRef]

66. Rajedran, D.; Pattanaik, A.K.; Khan, S.A.; Bedi, S.P.S. Iodine supplementation of Leucaena leucocephala diet for goats. I. Effect on nutrient utilization. Asian-Austr. J. Anim. Sci. 2001, 14, 785-790. [CrossRef]

67. Puchala, R.; Sahlu, T.; Davis, J.J.; Hart, S.P. Influence of mineral supplementation on 2,3-dihydroxypyridine toxicity in Angoragoats. Anim. Feed Sci. Technol. 1995, 55, 253-262. [CrossRef]

68. Santos-Ricalde, R.; Gutiérrez-Ruiz, E.; Novelo-Ucan, W.; Martinez-Romero, P.; Segura-Correa, J. Effect of feed restriction on intake of Moringa oleifera and Leucaena leucocephala and growth performance of rabbits. Trop. Anim. Health Prod. 2017, 49, 1685-1688. [CrossRef]

69. Raharjo, Y.C.; Cheeke, P.R. Palatability of tropical tree legume forage to rabbits. Nit. Fix. Tree Res. Rep. 1985, 3, 31-32.

70. Raharjo, Y.C.; Cheeke, P.R.; Patton, N.M. Evaluation of tropical forages and rice by-products as rabbit feeds. J. Appl. Rabbit Res. 1988, 11, 201-211.

71. Aduku, A.O.; Dim, N.I.; Hassan, W. Evaluation of tropical green forages for dry season feeding of rabbits. J. Appl. Rabbit Res. 1989, 12, 113-115.

72. Pasupathi, K.; Gopi, H.; Babu, M.; Kumanan, K. Carcass characteristics of rabbits fed with tree fodders. Ind. Vet. J. 2016, 93, 26-28.

73. Al-Amin, N.; Astuti, A.; Widi, T.S.M. Nutrient intake and performance of male New Zealand White rabbits fed different level of Leucaena leaf meal in pelleted complete diets. IOP Conf. Ser. Earth Environ. Sci. 2019, 387, 1-5. [CrossRef]

74. D'Mello, J.P.F.; Acamovic, T.; Walker, A.G. Evaluation of Leucaena leaf meal for broilers growth and pigmentation. Trop. Agric. 1987, 64, 33-35.

75. Aissiwede, S.B.; Dieng, A.; Chrysostome, C.; Hornick, J.L.; Missohou, A. Digestibility and metabolic utilization and nutritional value of Leucaena leucocephala (Lam.) leaves meal incorporated in diets of indigenous Senegal chickens. Int. J. Poul. Sci. 2010, 9 , 767-776. [CrossRef]

76. Dumorné, K. Effect of dietary inclusion of Leucaena (Leucaena leucocephala) and banana flour (Musa cavendishii) on performance of laying hens. Rev. Bras. Cien. Avic. 2018, 20, 725-730. [CrossRef]

77. Apata, E.S.; Ogungbesan, A.M.; Abiola-Olagunju, O.; Ogundele, G.J. Studies on carcass and meat quality attributes of broiler chickens fed graded levels of detoxified Leucaena leucocephala (Lam.) de wit basal diet. Trop. Agric. 2018, 95, $257-264$.

78. Ahmed, M.E.; Abdelatik, K.A. Effect of dietary levels of Leucaena leucocephala seeds on layers performance, egg quality and blood parameters. Int. J. Poul. Sci. 2009, 8, 475-479. [CrossRef]

79. Muir, J.P.; Massaete, E.S.; Tsombe, H.N. Effect of Leucaena leucocephala and Brassica napus on growth of pigs fed wheat bran diets. Liv. Res. Rural Dev. 1992, 4, 49-54.

80. Ekpenyong, T.E. Leucaena Leaf Meal. Non-Traditional Feeds for Use in Swine Production; CRC Press: Boca Raton, FL, USA, 1990; pp. 225-235.

81. Hasan, M.R.; Roy, P.K.; Akand, A.M. Evaluation of Leucaena leaf meal as a dietary protein source for Indian major carp (Labeo rohita) fingerlings. Aquaculture 1994, 124, 65-66. [CrossRef]

82. Bairagi, A.; Sarkar Ghosh, K.; Sen, S.K.; Ray, A.K. Evaluation of the nutritive value of Leucaena leucocephala leaf meal, inoculated with fish intestinal bacteria Bacillus subtilis and Bacillus circulans in formulated diets for rohu, Labeo rohita (Hamilton) fingerlings. Aquac. Res. 2004, 35, 436-446. [CrossRef]

83. Osman, M.F.; Eglal Omar, A.; Nour, A.M. The use of Leucaena leaf meal in feeding Nile tilapia. Aquacult. Int. 1996, 4, 9-18. [CrossRef]

84. Tiamiyu, L.O.; Okomoda, V.T.; Agbo, A.O. Nutritional suitability of Leucaena leaf meal in the diet of Clarias gariepinus. J. Fish. Sci. 2015, 9, 1-5. 
85. Sotolu, A.O.; Faturoti, E.O. Digestibility and nutritional values of differently processed Leucaena leucocephala (Lam. de Wit) seed meals in the diet of African catfish (Clarias gariepinus). Middle East J. Sci. Res. 2008, 3, 190-199.

86. Hegarty, M.P.; Court, R.D.; Thorne, P.M. The determination of mimosine and 3,4-dihydroxypyridine in biological material. Austr. J. Agric. Res. 1964, 15, 168-179. [CrossRef]

87. Sethi, P.; Kulkarni, P.R. Leucaena leucocephala A nutrition profile. Food Nutr. Bull. 1995, 16, 94. [CrossRef]

88. Hegarty, M.P.; Court, R.D.; Christie, G.S.; Lee, C.P. Mimosine in Leucaena leucocephala is metabolized to a goitrogen in ruminants. Austr. Vet. J. 1976, 52, 490. [CrossRef]

89. D'Mello, J.P.F. Chemical constraints to the use of tropical legumes in animal nutrition. Anim. Feed Sci. Tech. 1992, 38, 237-261. [CrossRef]

90. Hylin, J.W. Biosynthesis of mimosine. Phytochemistry 1964, 3, 1614. [CrossRef]

91. Ikegani, F.; Mizuno, M.; Kihara, M.; Murakoshi, I. Enzymatic synthesis of the thyrotoxic amino acid mimosine from cysteine synthase. Phytochemistry 1990, 29, 3461-3465. [CrossRef]

92. Lowry, J.B.; Tagendjaja, M.; Tagendjaja, B. Autolysis of mimosine to 3-hydroxy-4-1(h)pyridione in green tissues of Leucaena leucocephala. J. Sci. Food Agric. 1983, 34, 529-533. [CrossRef]

93. Murakoshi, I.; Kuramoto, T.; Haginiwa, J.; Fowden, L. Formation of S-methylcysteine from mimosine by Leucaena seedling extracts. Bioch. Bioph. Res. Comm. 1970, 41, 1009-1012. [CrossRef]

94. Tagendjaja, B.; Lowry, J.B.; Willis, R.B.H. Isolation of a mimosine degrading enzyme from Leucaena leaf. J. Sci. Food Agric. 1986, 37, 523-526. [CrossRef]

95. Hylin, J.W. Toxic peptides and amino acids in foods and feeds. J. Agric. Food Chem. 1969, 17, 492-496. [CrossRef]

96. Mauldin, E.A.; Peters-Kennedy, J. Integumentary System. In Pathology of Domestic Animals; Kennedy-Palmer, J., Ed.; Elsevier: Amsterdam, The Netherlands, 2016; Volume 1, pp. 509-736.

97. Fowden, L.; Lewis, D.; Tristram, H. Toxic amino acids: Their action as anti-metabolites. Adv. Enz. 1967, $29,89-163$.

98. Perry, C.; Sastry, R.; Nasrallah, I.M.; Stover, P.J. Mimosine attenuates serine hydroxymethyltransferase transcription by chelating zinc. Implications for inhibition of DNA replication. J. Biol. Chem. 2005, 280, 396-400. [CrossRef]

99. Pandey, A.K.; Dwivedi, U.N. Induction, isolation and purification of mimosine degradation enzyme from newly isolated Pseudomonas putida STM 905. Enz. Micr. Techn. 2007, 40, 1059-1066. [CrossRef]

100. Tsai, W.C.; Ling, K.H. Toxic action of mimosine-1. Inhibition of mitosis and DNA synthesis of HEp-2 cell by mimosine and 3,4-dihydroxypyridine. Toxicon 1971, 9, 241-247. [CrossRef]

101. Jones, R.J.; Hegarty, M.P. The effect of different proportions of Leucaena leucocephala in the diet of cattle on growth, feed-intake, thyroid-function and urinary excretion of 3-hydroxy-4(1h)-pyridone. Austr. J. Agric. Res. 1984, 35, 317-325. [CrossRef]

102. Prasad, J.; Paliwal, O.P. Pathological changes in experimentally induced Leucaena toxicity in lambs. Ind. Vet. J. 1989, 66, 711-714.

103. Hegarty, M.P.; Court, R.D.; Schinckel, P.G. Reaction of sheep to the consumption of Leucaena glauca Benth. and to its toxic principle mimosine. Austr. J. Agric. Res. 1964, 15, 153-167. [CrossRef]

104. Ram, J.J.; Atreja, P.P.; Chopra, R.C.; Chhabra, A. Mimosine degradation in calves fed a sole diet of Leucaena leucocephala in India. Trop. Anim. Health Prod. 1994, 26, 199-206. [CrossRef] [PubMed]

105. Jones, R.J.; Blunt, C.G.; Nurnberg, B.I. Toxicity of Leucaena leucocephala - effect of iodine and mineral supplements on penned steers fed a sole diet of Leucaena. Austr. Vet. J. 1978, 54, 387-392. [CrossRef] [PubMed]

106. Holmes, J.H.G. Toxicity of Leucaena leucocephala. II. Reduced fertility of heifers grazing Leucaena leucocephala. Pap. New Gui. Agric. J. 1980, 31, 47-50.

107. Holmes, J.H.G. Toxicity of Leucaena leucocephala for steers in the wet tropics. Trop. Anim. Health Prod. 1981, 13, 94-100. [CrossRef]

108. Dalzell, S.A.; Burnett, D.J.; Dowsett, J.E.; Forbes, V.E.; Shelton, H.M. Prevalence of mimosine and DHP toxicity in cattle grazing Leucaena leucocephala pastures in Queensland. Austr. Anim. Prod. Sci. 2012, 52, 365-372. [CrossRef]

109. Hashiguchi, H.; Takahashi., H. Toxicity of L-mimosine and its chelate forming nature with metal ions. Kum. Med. J. 1977, 30, 101-110.

110. Crounse, R.G.; Maxwell, J.D.; Blank, H. Inhibition of growth of hair by mimosine. Nature 1962, 194, 694-695. [CrossRef]

111. Christie, G.S.; Lee, C.P.; Hegarty, M.P. Antithyroid properties of 3-hydroxy-4(1H)-pyridone: Antiperoxidase activity and effect on thyroid function. Endocrinology 1979, 105, 342-347. [CrossRef]

112. Lee, C.P.; Christie, G.S.; Hegarty, M.P. Anti-thyroid and anti-perioxidase activity of some isomeric dihydroxy pyrodines. Thyroid Research III. In Proceedings of the 8th International Thyroid Congress, Sydney, Australia, 4-8 February 1980; p. 137.

113. Ghosh, M.K.; Samiran, B. Mimosine toxicity-A problem of Leucaena feeding in ruminants. Asian J. Anim. Vet. Adv. 2007, 2, 63-73. [CrossRef]

114. McSweeney, C.S.; Bamualim, A.; Murray, R.M. Ruminal motility in sheep intoxicated with 2,3-dihydroxypyridine. Austr. Vet. J. 1984, 61, 271-272. [CrossRef]

115. Ghosh, M.K.; Atreja, P.P.; Buragohain, R.; Bandyopadhyay, S. Influence of short-term Leucaena leucocephala feeding on milk yield and its composition, thyroid hormones, enzyme activity, and secretion of mimosine and its metabolites in milk of cattle. J. Agric. Sci. 2007, 145, 407-414. [CrossRef]

116. Akbar, M.A.; Gupta, P.C. Mimosine in subabul (Leucaena leucocephala). Ind. J. Anim. Sci. 1984, 37, $287-289$. 
117. Benge, M.D.; Curran, H. The use of Leucaena for soil erosion control and fertilization. In Leucaena Leucocephala: A Tree That Defies the Woodcutter; Benge, M.D., Ed.; Office of Agriculture, Development Support Bureau, Agency for International Development: Washington, DC, USA, 1981; Volume 6, pp. 1-13.

118. Wee, K.L.; Wang, S. Effect of post-harvest treatment on the degradation of mimosine in Leucaena leucocephala leaves. J. Sci. Food Agric. 1987, 39, 195-201. [CrossRef]

119. Sethi, P. Nutritional and Biochemical Aspects of Leucaena leucocephala. Ph.D. Thesis, University of Bombay, Department of Chemical Technology, Bombay, India, 1989.

120. Mali, J.M.; Kute, L.S.; Jambhale, N.D.; Kadam, S.S. Effect of heat processing on anti-nutrients in Leucaena seeds. Ind. J. Anim. Sci. 1990, 60, 383-385.

121. Tawada, S.; Hongo, F.; Sunagawa, K.; Kawashima, Y.; Yaga, S. A simple reduction method of mimosine in the tropical plant Leucaena. Sci. Bullet. Coll. Agric. 1986, 33, 87-94.

122. Hossain, M.A.; Mustafa, A.L.; Alam, M.; Khan, M.Z.A. Studies on the removal of mimosine from ipil-ipil (Leucaena leucocephala) seed. J. Bangl. Chem. Soc. 1991, 4, 83-85.

123. Hogo, F.; Tanaka, A.; Kawashima, Y.; Tarata, S.; Sunagawa, K. The effects of various kinds of mimosine reduced Leucaena meal on rats. Jap. J. Zootech. Sci. 1988, 59, 688-700.

124. Tagendjaja, B.; Lowry, J.B.; Willis, R.B.H. Optimisation of conditions for degradation of mimosine in Leucaena leucocephala leaf. J. Sci. Food Agric. 1984, 35, 613-616. [CrossRef]

125. Barros-Rodríguez, M.; Solorio, F.; Sandoval-Castro, C.A.; Sarmiento-Franco, L.A.; Rojas Herrera, R.; Klieve, A.V. Leucaena leucocephala in ruminant nutrition. Trop. Subtrop. Agroecosys. 2014, 17, 173-183.

126. Rincón, M.T.; Domínguez-Bello, M.G.; Lovera, M.; Romero, M.R. Degradation of toxic piridine diols derived from mimosine by rumen bacteria: I. Microbiological Aspects. Rev. Cient. 2000, 10, 222-232.

127. Halliday, M.J.; Pakereng, C.; Edison, R.G.; Ara, P.; Dida, P.R.; Nulik, J.; Hau, D.K.; Mcmillan, H.E.; Shelton, H.M. Effectiveness of inoculation with rumen fluid containing Synergistes jonesii to control DHP toxicity in ruminants in eastern Indonesia. Trop. Grass. 2019, 7, 252-257. [CrossRef]

128. Gupta, H.K.; Atreja, P.P. Influence of gradual adaptation of cattle to Leucaena leucocephala leaf meal on biodegradation of mimosina and 3-hydroxy-4(1H)-pyridone (3,4-DHP) in rumen, their levels in blood, fate and influence of absorbed DHP on thyroid hormones and liver enzymes. Anim. Feed Sci. Tech. 1998, 74, 29-43. [CrossRef]

129. Shelton, H.M.; Kerven, G.L.; Dalzell, S.A. An update on Leucaena toxicity: Is inoculation with Synergistes jonesii necessary? Trop. Grass. 2019, 7, 146-153. [CrossRef]

130. Halliday, M.J.; Padmanabha, J.; McSweeney, C.S.; Kerven, G.; Shelton, H.M. Leucaena toxicity: A new perspective on the most widely used forage tree legume. Trop. Grass. 2013, 1, 1-11. [CrossRef]

131. Halliday, M.J.; Panjaitan, T.; Nulik, J.; Padmanabha, J.; McSweeney, C.S.; Depamede, S.; KanaHau, D.K.; Fauzan, M.; Yuliana, B.T.; Pakereng, C.; et al. Prevalence of DHP toxicity and detection of Synergistes jonesii in ruminants consuming Leucaena leucocephala in eastern Indonesia. Trop. Grass. 2014, 2, 71-73. [CrossRef]

132. Glumac, E.L.; Felker, P.; Reyes, I. A comparison of cold tolerance and biomass production in Leucaena leucocepahala, L. pulverulenta and L. retusa. For. Ecol. Manag. 1987, 18, 251-271. [CrossRef]

133. Damascena, J.G.; Leite, G.L.D.; Silva, F.W.S.; Soares, M.A.; Guanabens, R.E.M.; Sampaio, R.A.; Zanuncio, J.C. Spatial distribution of phytophagous insects, natural enemies and pollinators on Leucaena leucocephala (Fabaceae) tree in the Cerrado. Fla. Entom. 2017, 100, 3.

134. Mehta, A.A.; Behera, L.K.; Sinha, S.K.; Kumar, R. Agroforestry tree for successful beekeeping. In Proceedings of the Conference An Evergreen Agriculture for Food Security and Environmental Resilience, Navsari, Gujarat, India, 2-4 February 2012; pp. 43-44

135. Do Nascimento, A.S.; Marchini, L.C.; Lopes de Carvalho, C.A.; Dias Araujo, D.F.; da Silveira, T.A. Pollen spectrum of stingless bees honey (Hymenoptera: Apidae), Parana State, Brazil. J. Entom. Zool. Stud. 2015, 3, 290-296.

136. Ngongolo, K.; Mtoka, S.; Mahulu, A. The abundance and pollinators' impact on seed setting of Leucaena lucocephala in Wazo Hill restored Quarry, Tanzania. J. Zool. Appl. Biosci. 2014, 1, 6-10.

137. Rogel Villanueva, G. Pollen resources used by European and Africanized honey bees in the Yucatan Peninsula, Mexico. J. Apic. Res. 1998, 38, 105-111. [CrossRef]

138. Meena Devi, V.N.; Ariharan, V.N.; Nagendra Prasad, P. Nutritive value and potential uses of Leucaena leucocephala as biofuel-A mini review. RJPBCS 2013, 4, 5515-5521.

139. Yusuff, A.S.; Lala, M.A.; Popoola, L.T.; Adesina, O.A. Optimization of oil extraction from Leucaena leucocephala seed as an alternative low-grade feedstock for biodiesel production. SN Appl. Sci. 2019, 1, 357. [CrossRef]

140. Khan, A.M.; Ali, S. Production of biodiesel and bioethanol from the legumes of Leucaena leucocephala. J. Biofuels 2014, 5, 76-82. [CrossRef]

141. Tudsri, S.; Chotchutima, S.; Nakamanee, K.; Kangwansaichol, K. Dual use of Leucaena for bioenergy and animal feed in Thailand. Trop. Grass. 2019, 7, 193-199. [CrossRef]

142. Benjakul, S.; Kittiphattanabawon, P.; Sumpavapool, P.; Maqsood, S. Antioxidant activities of lead (Leucaena leucocephala) seed as affected by extraction solvent, prior dechlorophylisation and drying methods. J. Food Sci. Technol. 2014, 51, 3026-3037. [CrossRef]

143. Aderibigbe, S.A.; Adetunki, O.A.; Odeniyi, M.A. Antimicrobial and pharmaceutical properties of the seed oil of Leucaena leucocephala (Lam.) De Wit (Leguminosae). Afr. J. Biomed. Res. 2011, 14, 63-68. 
144. Hernandez, P.M.; Abdelfattah, Z.M.S.; Elghandour, M.M.M.Y.; Cipriano-Salazar, M.; Cruz-Lagunas, B.; Camacho, L.M. Anthelmintic effects of Salix babylonica L. and Leucaena leucocephala Lam. extracts in growing lambs. Trop. Anim. Health Prod. 2014, 46, 173-178. [CrossRef]

145. Soares, A.M.; dos, S.; de Araujo, S.A.; Lopes, S.G.; Costa Junior, L.M. Anthelmintic activity of Leucaena leucocephala protein extracts on Haemonchus contortus. Braz. J. Vet. Jaboticabal 2015, 24, 396-401. [CrossRef]

146. Njunge, J.T.; Kaholongo, I.K.; Amutenya, M. Invasiveness and biomass production of Leucaena leucocephala under harsh ecological conditions of north-central Namibia. J. Trop. For. Sci. 2017, 29, 297-304.

147. Yoshida, K.; Oka, S. Invasion of Leucaena leucocephala and its effects on the native plant community in the Ogasawara (Bonin). Weed Technol. 2004, 18, 1371-1375. [CrossRef]

148. Witt, A.B.R. Biofuels and invasive species from an African perspective-A review. GCB Bioenergy 2010, 2, 321-329. [CrossRef]

149. Lowe, S.; Browne, M.; Boudjelas, S.; De Poorter, M. 100 of the World's Worst Invasive Alien Species A selection from the Global Invasive Species Database; ISSG, SSC, IUCN; Holland Printing Ltd.: Auckland, New Zeland, 2000; pp. 1-11.

150. Global Invasive Species Database (GISD). Species profile Leucaena leucocephala. Available online: http://www.iucngisd.org/ gisd/species.php?sc=23 (accessed on 26 February 2021).

151. Hata, K.K.; Suzuki, J.I.; Kachi, N. Fine-scale spatial distribution of seedling establishment of the invasive plant, Leucaena leucocephala, on an oceanic island after feral goat extermination. Weed Res. 2010, 50, 472-480. [CrossRef]

152. Sharratt, M.E.J.; Olckers, T. The biological control agent Acanthoscelides macrophthalmus (Chrysomelidae: Bruchinae) inflicts moderate levels of seed damage on its target, the invasive tree Leucocaena leucocephala (Fabaceae), in the KwaZulu-Natal coastal region of South Africa. Afr. Entomol. 2012, 20, 44-51. [CrossRef]

153. Chiou, C.R.; Wang, H.H.; Chen, Y.J.; Grant, W.E. Modeling potential range expansion of the invasive shrub Leucaena leucocephala in the Hengchun Peninsula, Taiwan. Invasive Plant Sci. Manag. 2013, 6, 492-501. [CrossRef]

154. Anonymous. Code of Practice. Principles of the Best Management Code of Practice. The Lucaena network. Australia. 2020. Available online: https:/ / www.Leucaena.net/fact-sheets (accessed on 23 February 2021).

155. Wheeler, R.D.; Brewbaker, J.L. Leucaena research for Hawaiian forest and rangeland applications. Trans. West. Sect. Wildl. Soc. 1988, 24, 94-97.

156. Campbell, S.; Vogler, W.; Brazier, D.; Vitelli, J.; Brooks, S. Weed Leucaena and its significance, implications and control. Trop. Grass. 2019, 7, 280-289. [CrossRef] 